\title{
The Discourse of Partnership and the Reality of Reform: Interrogating the Recent Reform Agenda at Initial Teacher Education and Induction Levels in Ireland
}

Judith HARford ${ }^{* 1}$ AND Teresa O'Doherty ${ }^{2}$

$\propto$ Over the last decade, teacher education in Ireland has experienced radical reconceptualization and restructuring at both initial teacher education [ITE] and induction levels, with reform of continuous professional development now in the planning phase. The establishment of the Teaching Council (2006) as a statutory, regulatory body, with a role in the review and accreditation of teacher education, increased the visibility of and policy focus on teacher education. Significant reform of initial teacher education was announced in 2011 that included both an extension of the duration of programmes and, most notably, the period the student teachers were to be engaged in school-based professional development. This increased period has been accompanied by a shift in the understanding of what is involved in practicum and implies a redefinition of the respective roles of the university and the school, and the development of a new form of partnership between both agencies. The period of induction and probation has also become an area of reform with an emphasis on school-based coaching and the evaluation of newly qualified teachers, which devolves decisions on teachers' full recognition and membership of the profession, to principals and colleagues. This shift, which changes the established approach to induction for primary level teachers, has resulted in the withdrawal of cooperation with this policy by the main teacher union and to the implementation process being stymied. Both policy developments bring the concept of partnership within Irish education into sharp focus: a partnership between schools and universities in ITE, but also partnership in policy development and implementation in the case of induction.

Keywords: teacher education reform, partnership, policy-making processes, initial teacher education, induction

$1 \quad{ }^{\star}$ Corresponding Author. School of Education, University College Dublin; judith.harford@ucd.ie.

2 Mary Immaculate College, Limerick. 


\section{Diskurz partnerstva in realnost reform: preizpraševanje nedavnega programa reform začetnega izobraževanja učiteljev in ravni pripravništva na Irskem}

Judith Harford in Teresa O’Doherty

$\propto$ V zadnjem desetletju je izobraževanje učiteljev na Irskem doživelo radikalne rekonceptualizacije in prestrukturiranje začetnega izobraževanja učiteljev [ZIU] ter ravni pripravništva, ki jih spremljajo reforme nadaljnjega strokovnega izobraževanja in usposabljanja, ki je trenutno v fazi načrtovanja. Vzpostavitev Učiteljske zbornice (2006) kot zakonsko predpisanega regulativnega telesa, ki igra pomembno vlogo pri evalvaciji in akreditaciji programov izobraževanja učiteljev, je povečalo vidnost in preusmeritev pozornosti na izobraževanje učiteljev. Znatna reforma začetnega izobraževanja učiteljev je bila sprejeta leta 2011. Vključevala je podaljšanje izvajanja programov in še zlasti opazno obdobja, ko so študentje učitelji vključeni $v$ na šolo usmerjeni strokovni razvoj. To podaljšanje obdobja je spremljal premik v razumevanju, kaj naj obsega praktikum ter implicira redefinicijo vlog univerz in šol pa tudi razvoj nove oblike partnerstva med obema akterjema. Obdobje pripravništva in poskusne dobe je prav tako postalo področje reform s posebnim poudarkom na šolo osredinjenega mentorstva in evalvacije na novo usposobljenih učiteljev, kar prenaša odločitve o učiteljevem polnem prepoznanju in članstvu v poklicu na ravnatelje in kolege učitelje. Temu premiku, ki spreminja uveljavljen pristop mentorstva, učiteljstvo nasprotuje. Obe usmeritvi razvoja politik izpostavljata koncept partnerstva v izobraževanju na Irskem v izostren fokus: partnerstva med šolami in univerzami v začetnem izobraževanju učiteljev pa tudi partnerstva $v$ razvoju politik in implementacije ob uvajanju.

Ključne besede: reforma izobraževanja učiteljev, partnerstvo, proces sprejemanja odločitev, začetno izobraževanje učiteljev, pripravništvo 


\section{Introduction}

This paper examines two recent reforms in Irish teacher education and two aspects of partnership: the partnership between universities and schools as a core part of initial teacher education, and the partnership in policy development and implementation in the area of induction. Through an analysis of key documents which underpin the reform agenda, it argues that the partnership metaphor has been loosely employed in the Irish context to denote consensus and collaboration. The absence of any real interrogation of what partnership means, how it can be nurtured, and what supports are required to promote authentic and complementary partnership between schools and universities, or between and within schools means that policy decisions, made at the central level and which are implemented by practitioners, are floundering. It further contends that the ubiquitous nature of the discourse on partnership evident across the policy space legitimises the top-down policy development and reform, in the case of school placement and latterly induction, and masks the lack of any sustainable partnership framework to support these initiatives, a factor that threatens the very essence of the reform agenda.

\section{Teachers and teacher education in Ireland}

Teaching in Ireland is an all-graduate profession, with the entry requirements and the number of available places on courses regulated by the State Higher Education Authority, in collaboration with the State Department of Education and Skills. Teacher preparation programmes may be concurrent or consecutive, and both routes retain high status and are over-subscribed, typically attracting a very high calibre of entrant (Harford, 2010). Commenting on the high quality of entrants to teaching in Ireland, a recent report on initial teacher education in Ireland, the Sahlberg Report, noted 'the academic standard of applicants is amongst the highest, if not the highest, in the world' (Sahlberg, 2012, p. 19). Admission to publicly-funded, undergraduate teacher education programmes for all school levels, is highly competitive; primary-level teacher education programmes attract recruits from the top $15 \%$ of all academic achievers in the Leaving Certificate Examination (Coolahan, 2003; Heinz, 2008, 2013; Hyland, 2012), while the majority of entrants to second-level teaching are high achievers at the undergraduate level (Harford \& O'Donoghue, 2010). Teacher unions and associations hold a particularly strong position in the education landscape and are not just concerned with the pay and conditions of their members. They are also professional organisations that have historically engaged in 
policy development and 'facilitate and provide a means of expression of teachers' collective opinion on matters affecting the interests of education and of the teaching profession' (INTO, 2014, p 1). They actively contribute to debates in education, publish research, and issue position papers on matters that pertain to the professional lives of teachers.

The student-teacher body remains largely homogenous, reflecting trends across the USA, Australia, and Northern Ireland, with the majority being white and from the dominant culture (Moran, 2008; Schleicher, 2012). This is despite the fact that Irish society has undergone significant demographic change during the last ten years, with its school populations significantly diversified through immigration (Devine, 2011; Smyth et al., 2009). Although traditionally a homogenous society characterised by mass emigration at various intervals, Irish society has witnessed significant inward migration over the last fifteen years, the result of a growing demand for labour in an expanding economy. Hyland (2012, p. 10) argues that 'the teaching profession in Ireland, especially at primary school level, is less culturally and ethnically diverse than in other OECD countries. The Catholic-based tradition of education in Ireland and, in particular, the Irishlanguage requirement for primary level teachers are potential reasons for this (O’Donoghue \& Harford, 2011). Similarly, in line with international trends, the majority of student teachers are female (Hyland, 2012), yet the majority of senior management positions in education are held by men (Cunneen \& Harford, 2016). Again, this reflects international trends (Fuller \& Harford, 2016).

Whilst ensuring high-quality initial teacher education is a key concern across the OECD (Schleicher, 2012), the emphasis on and visibility of ITE on the policy landscape is a relatively recent development in the Irish context. The structure and content of teacher education had remained the same for many decades prior to the policy developments of 2011. At primary level, the dominant route for entry to the teaching profession was the three-year BEd programme, which was introduced in 1974, and offered in colleges associated with and accredited by universities. This programme, although responding to curricular reforms, changing pedagogies, incorporating reflective practice, and implementing the European Credit Transfer system under the Bologna process, remained structurally intact for almost four decades (O'Doherty, 2014). At the post-primary level, the dominant entry route was the Higher Diploma in Education (H.Dip.), a one-year postgraduate university programme, which was established in 1912. Reflecting the diversification of school types and subjects at the post-primary level, the H.Dip., which was rooted in the classical tradition, was supplemented by a number of concurrent teacher education programmes catering for specialist teachers in the applied subjects from the 1970s onward. 
Despite the emergence of new ITE providers, the structure and underlying philosophy of Irish initial teacher education persisted for decades. Given the increase in the number of programmes (more than 40 in 2012) provided by nineteen recognised providers, (Hyland, 2012), teacher preparation was fragmented with little consistency in the approach to, and content of, teacher education across the state.

\section{The Culture of Partnership in Irish Education}

Partnership in Irish education is rooted in the social and economic planning process that was dominant during the last decades of the twentieth century. This process, premised on an inclusive, consultative and democratic approach to policy development, was best evidenced through the work of the National Education Convention (NEC) in 1993. This two-week convention facilitated structured multi-lateral dialogue involving 43 organisations and set the tone for what was to become 'a distinctive consultative tradition for education policy' (Coolahan, 2011). The NEC set out to:

[...] encourage participants to clarify viewpoints: to question, probe and analyse varying perspectives; to foster multi-lateral dialogue and improve mutual understanding between sectoral interests; to explore possibilities of new ways of doing things and to identify areas of actual or potential agreement between different interest groups (Coolahan, 1994, p. 1).

In a dynamic and authentic manner, participants engaged in a robust manner and the NEC, while a 'celebrated example of the partnership approach to education policy-making' (Gleeson, 2004, p. 50), was critical to setting the direction of future policy development. Following a similar format, the National Forum on Early Childhood Care and Education was held in 1998, and consultative fora were held on adult and continuing education, which shaped the first coherent policy on lifelong learning. Later, in 2003, a consultative forum was convened which focussed on the teaching career while in June 2008 , a consultative conference was held on 'The Governance Challenges for Future Primary School Needs. More recently, the working sessions of the Forum on Patronage and Pluralism (2011) were public events, available to view live on-line, with some 246 submissions being published. In addition to consulting with stakeholders and individuals, two consultation events were held with children in order to contribute to a better understanding of their experiences of religious education in primary schools (Coolahan et al., 2012). Each of these successive consultative processes created the platform for policy development, but also established an expectation 
that significant policy decisions in education would be the consequence of a deliberative process that included authentic consultation with all stakeholders. The inclusion of the 'social partners' in education bodies such as the NCCA established in 1987, is further evidence of the commitment of the state at that time to partnership; while the membership is determined by the Minister for Education and Skills, the 25-member council comprises nominees of school management bodies, teacher unions, parents' organisations, industry and business interests.

However, the process of representation is not always apolitical, and Gleeson (2004, p. 116) has argued that the teacher unions and managerial bodies control the NCCA. Despite the relative power of the various interest groups and the suggestion that a 'strong partnership rhetoric can mask a "political elite" (Gewirtz \& Ozga 1990, cited by Looney, 2014, p. 11), the concept of partnership remains highly valued in Irish education. The fact that so many organisations are represented on numerous fora, such as the NCCA, the National Council for Special Education (NCSE) and the Standing Conference of Teacher Education North and South (ScoTENS), has enabled the forging over time of strong professional relationships between departmental officials, teacher educators and the teacher unions. These relationships are not 'cosy' but are of the level that enable clear communication, realistic dialogue, and generate opportunities for collaboration. Through a consultative and incorporative tradition (Nicholls, 2015), characterised by 'mature democratic process[es]', Coolahan, (2011) argues that significant policy developments have been negotiated, which have contributed to the modernisation of Irish education. This approach towards policy, based on partnership, reflects a wider policy space. Partnership in teacher education has long been advocated by those involved in policy review. Since Furlong's study (1988) commissioned by the UK's DES in 1982, a partnership approach has become integral to many teacher education programmes internationally (Mutton, 2015). A 'profession based on partnership' is one of the four Common European Principles for Teacher Competences and Qualifications (European Union, 2008). Close partnerships and collaborative links between schools and initial teacher education providers is a key indicator of successful programmes (Darling-Hammond, 2006; Maandag et al., 2007).

Traditionally, university/college-led teacher education in Ireland has been highly dependent on schools, where the universities assume full responsibility for the planning, delivery, and assessment of the programme, and the schools are the sites for 'teaching practice'. While Irish teachers are co-operative and generous in their guidance of student teachers, it has been recognised for some time that 'there is significant scope for improving the linkages between schools and education departments in the interests of improved teacher education in Ireland' 
(Coolahan, 2001, p. 354). Clearly indicating that partnership needed to be enhanced, Kellaghan (2002, p. 121) suggested that, 'the practical knowledge of competent and experienced teachers that could play an important role in students' development is not adequately developed. Within the Irish context, the centrality of revised and more extensive university-school relationships to quality teacher education programmes had been acknowledged in advance of the establishment of the Teaching Council, and it would seem that, in theory at least, there was a readiness within the system to embrace a new approach. However, a rather loose articulation of what partnership represented, 'the processes, structures, and arrangements that enable the partners involved in school placement to work and learn collaboratively in teacher education', (Teaching Council, 2013, p. 6), the lack of a proper funding structure and a climate of 'reform overload' mitigated against any real cultural shift in partnership models.

\section{The Reform Agenda in Initial Teacher Education}

Following an extended period of stability, the establishment of the Teaching Council, the statutory body with responsibility for regulating the teaching profession, in 2006, was a significant development on the education landscape (O’Doherty \& Harford, 2016). Universities and colleges had exercised high levels of institutional autonomy in relation to the content and nature of teacher education programmes with little state intervention or regulation. This situation has changed considerably, and teacher education has become the object of state intervention and regulation, in a period when the government is seeking to recapture economic prosperity and competitiveness. In the context of Ireland's poor national performance in PISA, and influenced by economic regeneration and perceptions about international competitiveness, the Department of Education and Skills [DES] decided to extend the duration of ITE programmes to provide additional time for the development of teachers' skills in teaching literacy and numeracy (DES, 2011, July).

The Teaching Council, charged with the remit to regulate the quality of initial and continuing teacher education, has dramatically changed the dynamic and process of reform in Irish education within a five-year period. Within this period, the Council had issued criteria for the accreditation of all programmes and published a series of policy documents relating to the continuum of teacher education across the career cycle. All teacher education programmes leading to registration must be rigorously reviewed and professionally accredited by the Teaching Council. Since September 2012, in order to retain their professional accreditation from the Teaching Council, all concurrent (undergraduate) 
programmes of initial teacher education, must be of four years' duration (240 ECTS credits), and school placement must comprise $25 \%$ of the programme with a minimum of 24 weeks in schools. Since September 2014, all consecutive (postgraduate) programmes of initial teacher education are of two years' duration (120 ECTS credits), validated at master's level, with a minimum of $40 \%$ of the programme and 30 weeks of student time being dedicated to school placement. In practice, this reconceptualisation has led to a detailed articulation of the optimal design and content of programmes, with a renewed emphasis on literacy and numeracy, and enhanced provision in ICT, special education, and assessment, as well as an enrichment of both the duration and nature of school placement within the programmes (O’ Doherty, 2014). Although the introduction of master's level teacher education has been widely welcomed (Coolahan, 2013), recent research (O’Doherty \& Harford, 2016) suggests that the reform and reconceptualisation of ITE has resulted in greater demands being placed on schools in relation to 'partnership'; that the timing of the reform agenda, as well as the lack of a resource base, is problematic; moreover, that capacity and 'good will' within the system are now under threat.

The partnership between HEIs and schools in support of the practicum component of initial teacher education has always been regarded as a central part of the success of initial teacher education contributing to the calibre of a student teacher who eventually joins the profession. Historically, however, the relationship between schools and HEIs has been an informal one, based on good will. The lack of formalised school-university partnerships has been widely documented (Conway et al., 2009) with some scholars highlighting the fact that student teachers have traditionally been treated as 'fully qualified, professional teachers and entrusted with responsibilities that were not appropriate to their status' (Mullins, 2004, p. 38). One of the key recommendations of the Sahlberg Report is the need to develop more systematic partnerships between HEIs and schools. The Teaching Council has taken up this mantra, recognising that ITE represents the 'foundation of the teacher's career', yet at the same time conceding that ITE has traditionally relied on ad hoc relationships between HEIs and schools (Teaching Council, 2011b, p. 11).

Cognisant of the need to provide a more structured basis for effective school-university partnerships, the Teaching Council has called for the development of 'new and innovative school placement models [...] developed using a partnership approach, whereby HEIs and schools actively collaborate in the organisation of the school placement' (Teaching Council 2011b, p. 15). The cornerstone of the reform agenda is a more sophisticated experience of the practicum, which is predicated on an enhanced relationship between schools and 
university education departments:

"School placement is designed to give the student teacher an opportunity to learn about teaching and learning, to gain practice in teaching, to apply educational theory in a variety of teaching and learning situations and school contexts and to participate in school life in a way that is structured and supported. It replaces the term 'teaching practice' and more accurately reflects the nature of the experience as one encompassing a range of teaching and non-teaching activities (Teaching Council, 2013, p. 6)."

In its Criteria and Guidelines for Programme Providers (2011b), the Teaching Council announced a significant policy shift from 'teaching practice' to 'school placement' (Sugrue \& Solbrekke, 2015, p. 6). Inherent to the revised approach to practicum was the expectation that partnership built on the following principles would be achieved:

- host schools being communities of good professional practice

- greater levels of responsibility being devolved to the profession for the provision of structured support for student teachers. Structured support should include mentoring, supervision and constructive feedback on practice. In that context, students should be afforded opportunities for critical analysis of the experience, as well as observation of, and conversations with, experienced teachers whole school approach to supporting student teachers, under the guidance of principals as leaders of learning - $\quad$ an enhanced partnership between the HEI Placement Tutor and the Cooperating Teacher

... the school placement should afford student teachers the opportunity to plan and implement lessons and receive constructive feedback. (Teaching Council, 2011b, pp. 16, 17)

The 2011 Policy is explicit on the content, nature, and duration of placement and of the level of partnership required in order to deliver the desired school-based support to student teachers. However, in the specific School Placement Guidelines which were subsequently published (2013), the level of expectation was somewhat diluted. The benefits of reconceptualising the school placement experience were identified, namely:

- It will enhance the school placement experience for student teachers

- It will enrich learning outcomes for both current and future learners

- It will deepen the professional satisfaction and improve the status of teachers (Teaching Council, 2013, p. 7). 
The School Placement Guidelines (2013) are more nuanced than the previous iteration and recognise 'the goodwill of teachers and other partners and the voluntary nature of their participation' (2013, p. 10). They further outline the desirability of co-operating teachers and school principals providing structured support to student teachers but acknowledge this support was only possible 'having regard to capacity' (p. 15). The Guidelines are mostly aspirational, with little or no mention of exactly how any sea change in the school-university partnership model is to be realised, operationalised, or resourced (O'Doherty \& Harford, 2016). Particularly absent from the Guidelines is any reference to the selection and professional development of co-operating teachers who work with student teachers on school placement. Currently, co-operating teachers are either self-selecting or selected by school principals; the criteria for selection may be linked to their professional and personal capacity to undertake this role, yet it may also be linked to other variables, such as timetabling issues or the need to supplement an ineffective experienced teacher with a student teacher. Schools are not obliged to take student teachers, and increasingly schools at the primary level are reluctant to accommodate students particularly for the extended ten-week placement (Cotrell, 2012). Given the Teaching Council's requirement that students engage in multiple settings for extended periods, it would appear that inadequate consideration was given at the outset to the scalability of the project being promoted. Based on a survey of ITE providers, Ó Neill (2015) suggests that approximately 8600 primary school placements are required each academic year to accommodate the needs of student teachers. While there are 21,724 mainstream class teachers in primary schools (DES, 2015-16 Key statistics), as many as $25 \%$ of this cohort may be ineligible/unable to accept a student teacher at any given time. As a consequence, to accommodate the current needs of initial teacher education, the Council expects that one in every two eligible teachers will accept a student on placement each year, often for an extended period; delivering on this expectation is extremely challenging. At the post-primary level, the demand for classes is no less challenging given the range of subjects and class levels required by students. Such levels of placement are unprecedented in the literature on teacher education and in the partnership literature. While the scale of the practical and logistical elements is of concern, so too is the absence of a dialogue on the essence of teacher education, what is appropriate content, and pedagogy of ITE.

The Teaching Council's recommendations on partnership in School Placement are premised on the control, management and assessment of placement, as well as the content and thrust of ITE programmes remaining the responsibility of the universities. While there is an assumption that teachers will 
comply with requests to accept student teachers, to facilitate the learning objectives as outlined by the ITE provider, and formally mentor the students, there is no suggestion within the documentation that the design and content of ITE programmes would be a shared responsibility. While the limited articulation of the respective roles and responsibilities of the various actors in school placement (cooperating teachers, HEIs, schools, student teachers) is to be welcomed (Teaching Council, 2013), the fact that these guidelines do not address fundamental principles of partnership is of concern. Partnership, as outlined by the Teaching Council, does not promote shared ownership of the process, agree pedagogic principles, require joint strategic planning and implementation of placement, establish clear division of roles and responsibilities, build effective and regular communication processes, or fundamentally demand strong commitment of the partners involved (Mutton, 2015; Wanni et al., 2010). The HEIs dominate the relationship, where they request placements, and schools and individual teachers may grant access to their classrooms. Achieving full placement for students in a 'partnership' process, where there is no shared understanding of the principles of teacher education, an infrastructure to establish real and shared responsibility for school placement is absent, and where traditional goodwill and professional courtesy are the only bases for engagement, is unsustainable in the long term.

\section{Reform Agenda at Induction Level}

The Teaching Council's Policy on the Continuum of Teacher Education (2011a), which was the vision document for the reform of initial teacher education, also focused on the induction and in-career development needs of teachers. On completion of their ITE programme graduates are not fully recognised teachers, and must undergo a probation process before attaining qualified teacher status. Traditionally, probation for newly qualified primary level teachers required that they completed a specified period of service within a school, and were deemed competent by the Inspectorate, who inspected and formally assessed the performance of the newly qualified teacher (NQT) on two occasions. At post-primary level, responsibility for probation resided with principals who signed off on the NQT's suitability once a specified period of post-qualification employment had been completed. NQTs were expected to perform at the same level and with the same responsibilities as experienced teachers, from their first day of employment within the system. The Review of National Policies for Education (OECD, 1991, p.101) was critical of Ireland's approach to induction, which it deemed 'ad hoc and incomplete', and stressed 
that induction should form part of a 'coherent pattern of the professional career and regarded as an essential component of a policy for maintaining the quality of schools and of teachers'. Although teacher unions and ITE providers actively canvassed for support for beginning teachers throughout the 1990s, the National Pilot Project on Teacher Induction (NPPTI) was not established until 2002 (O’Doherty \& Deegan, 2009, p. 23). This pilot project, which continued until 2010, was a partnership between the Department of Education, the teacher unions, the HEIs, and the participating schools. While the project experienced several phases and experimented with various approaches, the positive role of mentors within a whole school approach to induction emerged as the primary finding of the project. During this project, induction occurred in parallel with probation, and the Inspectorate continued to assess NQTs' performance as a condition of probation and full recognition. The continued role of the Inspectorate was central to both the acceptance of the project within schools and the development of the mentor-mentee relationship (Smyth et al., 2016, p. 4). Building on the experience of the NPPTI, in 2010, the Teaching Council launched the National Induction Programme for Teachers (NIPT). Although engagement with the programme was initially on a voluntary basis, since 2012, all NQTs have been required to participate in the programme and to attend 24 hours of induction workshops. Scheduled in the late afternoon or evening and located in education centres/outreach venues, the two-hour workshops focus on the following themes: working as a professional; planning and preparation; classroom management and organisation; working with parents; child protection; assessment; behaviour management; literacy; numeracy; differentiation; inclusion; Gaeilge (primary teachers) / transition from primary school (post-primary teachers).

Following a decision of the Minister for Education and Skills, the Teaching Council was charged with establishing common procedures for the induction and probation of teachers at both primary and secondary levels (DES, 2012, p. ix). The Council proposed, as outlined in the Career Entry Professional Programme (CEPP), that the teaching profession and specifically principals of schools would assess and approve the competence of NQTs (Teaching Council 2012). The CEPP proposals were circulated for consultation in January 2012 with the intention that the new programme would be implemented on a phased basis from September 2012. The Council initiated a comprehensive consultation process; between January and March 2012 Council members and the executive met with management bodies, teachers' and principals' representatives, ITE providers, education centre directors, school principals, mentors and the National Induction Programme for Teachers (NIPT). The Council also invited 
written feedback and by 27 March 2012, 250 individuals and organisations had made submissions (Teaching Council, 2012, p. 23). Reminiscent of the democratic processes involved in policy development within Irish education, and in evident response to the serious concerns surrounding the proposals described within the revised probationary process, on 2 April the Irish Primary Principals' Network (IPPN, 2012) announced to its members that the Teaching Council had withdrawn the CEPP document.

Committed to revising the induction and probation process experienced by NQTs, the following March the Teaching Council instituted a single model of school-based induction and probation for all NQTs to be piloted over the 2013-2015 period. Under this pilot initiative, called Droichead (the Irish word for 'bridge'), in addition to participating in a minimum of 20 hours' professional development workshops, NQTs were supported by a school-based Professional Support Team (PST). The PST comprises a team of experienced teachers, including a principal and mentor, who work collaboratively to support the NQT during the induction process (Teaching Council, 2015). The PST engage in multiple observation and feedback sessions with the NQT, and the process includes both assistance and assessment; the PST provide formative and summative assessment linked to four criteria for full registration as a teacher (Smyth et al., 2016, p. 4). There were more than 300 schools at both primary and post-primary levels registered for Droichead with 280 NQTs participating in the process in 2015/6 (Smyth et al., 2016, p. 8). Central to the Droichead model is the integration of school-based assistance and assessment, and for successful completion, the NQT was required to have 'demonstrated an ability to practice independently as a qualified, fully registered teacher' (Smyth et al., 2016, p. 8). To satisfy this criterion, a member of staff had to observe the NQT teach on a number of occasions and to make the professional decision on whether or not the NQT had reached a satisfactory level of competence. In a system that has had a culture and tradition in which, since 1819 , decisions about teachers' competence have been made by the inspectorate, this represented a significant shift for all concerned. Professional development was provided to the principals, mentors, and staff in participating schools and cluster meetings were held where participants shared their experiences of the pilot. Additional support was also available from the NIPT and an inspector assigned to that cluster (Smyth et al., 2016, p. 6).

A recent review of the Droichead programme (Smyth et al., 2016), commissioned by the Teaching Council, found that more than $50 \%$ of schools that participated in this voluntary programme had been engaged with the earlier NPPTI and the majority of Droichead schools had staff who had previously 
been engaged in the mentoring project. Among the mentors surveyed, over a third (37 percent) had previously been a mentor in the school and over half (54 percent) had received mentoring training prior to joining Droichead (Smyth et al., 2016, p. 50). The role of the principal was central to the success of the programme in schools, and a significant minority of principals (four out of ten) had themselves trained as mentors. While the degree of staff buy-in to Droichead varied within and between schools, some degree of staff buy-in emerged as key to the successful implementation of the programme. Similarly, taking part in Droichead had changed practices within the schools, but the extent to which such changes went beyond the core Professional Support Team varied from school to school. The review observed that the dominant focus within Droichead schools was one of support and assistance and that the culture within schools prioritised coaching and involvement of the NQT within the wider life of the school, over assessment (p. 124). Participating NQTs referred to the school-based assessment process as being more 'authentic' than a performance for the visiting inspector (p. 125), and NQTs in Droichead schools reported lower levels of stress and slightly higher levels of confidence than those in non-Droichead schools (p. 201). However, time was a significant challenge within the project; time to have professional conversations, meetings and to conduct observations. Much of the meetings with the PST occurred outside of class time, and only half of schools fully used the release time allocation. More than half of the NQTs said they had met with their mentor more than ten times during the process, and NQTs were observed between two to four times, with a fifth of schools reporting that the NQT had been observed on five or more occasions (p. 199). Overall there were high levels of satisfaction with Droichead among PST members and the NQTs; participation in the process was deemed to have benefits for schools in providing structured support for NQTs, providing CPD for staff and promoting a positive collaborative learning culture within schools.

In the Review's concluding comments, the team referred to the pre-existing network of formal and informal supports in schools and noted, 'Schools with a stronger legacy of teacher collaboration assumed greater ownership of the process and used it to support a school-wide approach to teaching and learning' (p. 204). Elsewhere they observed, 'on average, ownership of Droichead, school-wide support for teaching and learning and adaptation of procedures appeared more established in the primary than in the second-level schools visited' (p. 170). It is inevitable that the decade of engagement with the NPPTI at primary level influenced this level of ownership and engagement with Droichead. 
This review of Droichead substituted for a wider consultation in relation to the introduction of a revised policy of probation. Based on the positive review of Droichead, the Teaching Council announced that the process of the school-based concept of induction would be implemented on a phased basis in all schools from September 2016. Given the radical departure from established practices and in the absence of a negotiated agreement on this policy, the INTO balloted primary level teachers, and $91 \%$ of voters rejected the roll-out of Droichead. Consequently, the INTO has directed its members ' $[. .$.$] not to co-operate$ with/participate in Droichead or any form of probation/induction that does not include fully external evaluation for all NQTs, with effect from 1 July 2016' (INTO, 2016). The implementation of a top-down policy, which has not been agreed with teachers, who are opposed to assuming responsibility for the evaluation of their colleagues, does not seem promising. The imposition of a policy that has ignored teachers' concerns has created an impasse in Irish education, and it is unlikely that the current iteration of the Droichead programme, which disrupts the long-standing culture and tradition of probation in schools, will be implemented in autumn 2016.

\section{Discussion and Implications}

This paper has considered two particular forms of partnership that are currently dominant features of the discourse of Irish teacher education. As early as 1984, Alexander identified some of the complexities associated with professional partnerships, and concluded, 'the comfortable language of 'partnership' conceals more intractable issues' (Alexander, 1984, p. 142, cited by Mutton, 2015, p. 201). The 'delicacy' required in the promotion of partnerships is often ignored and the initial step of getting all relevant people involved is frequently overlooked (OECD 2006). Within the Irish context, the social partnership processes that evolved as part of policy development since the 1980s have left a strong legacy. There is an expectation in Irish education that consultation is authentic, purposeful, and that reforms are negotiated. Within such an approach, genuine conversations about real issues are demanded, and discussions on values are at the core of such conversations. Such approaches enable the coming to a deeper understanding of the issues and, while not always achieving consensus, provide a well-laid foundation for reform. As outlined in the characteristics of partnership, it is important to create open communication, to develop a common vision for the project, but also to share ownership and responsibility for the project. Parity of esteem in the design of and decision making for projects is a further essential component. 'Partnership' is not just 
about adequate consultation, joint goal setting, establishing respective roles and responsibilities, but also about setting a structure in place to support and scaffold partnership. It is also central to the fostering of innovative teaching and learning communities in which there is a bridge between theory and practice and between practitioners and those engaged in academic research (OECD, 2015). In some contexts, partners have moved beyond the inclusion of school and university personnel to also consider the inclusion of business and civil society partners (Halasz, 2016). As Halasz points out, 'the emerging new way of understanding the nature of the professional knowledge of teachers, and understanding the way it is created, shared and acquired sheds new light on the cooperation between schools and universities' (p. 5). It also gives rise to the creation and development of school-university partnerships as a primary strategic field in teacher education.

It is interesting to consider to what extent, if any, the two cases outlined in this paper meet the criteria for 'partnership. The shift from 'teaching practice' to 'school placement' was announced by the Teaching Council within the Initial Teacher Education: Criteria and Guidelines for Programme Providers (2011) and further expanded upon in the revised Guidelines for School Placement (2013); central to this policy was the extension of the time students were to spend in schools, and it became evident that full responsibility for communicating and implementing the policy shift was to be carried by the ITE providers. While the language suggested a radical departure, partnership as a 'pedagogical concept', which focuses on a shared pedagogy and agreed curriculum of ITE was not at the heart of the policy. The dominant model of partnership promoted within the policy is that of 'expert-client' (Mutton, 2015), where the role of the HEIs is privileged over that of the practitioners. Recognising the absence of a systemic approach to school placement, the current Minister of Education and Skills has commented:

The new placement process is based on the development of a partnership approach between Higher Education Institutions and schools. Much progress has been made towards the development of that partnership approach. Based on engagement with the Higher Education Authority, the Teaching Council has identified the need for a forum that includes all HEIs providing programmes of ITE in Ireland, and a clear, time bound commitment to agreeing practical measures, including a national IT-based system, that will enhance the school placement experience for all parties to the process, and facilitate access by students to opportunities for same. I understand that the HEA and the Council will meet shortly to progress this matter (Bruton, 2016, emphasis added). 
While this commitment to take practical measures to support placement is to be welcomed, there is no reference to initiating a wider consultation, involving teachers, schools or parents in this forum, and the concept of an unequal and unbalanced partnership persists. If a vision for a reconceptualised school placement process is to be developed, where schools are sites for clinical placements and formally recognised partners with initial teacher education providers, enabling students to research and test new methods and approaches in collaboration with class teachers, then the discussion with the partners needs to be deeper and more extensive than proposed. It is also worth questioning why, in a period of radical re-structuring, a more innovative model of HEI school partnership is not being established? Why has the issue of meaningful partnership between schools and universities and resourcing such a partnership never reached the 'active agenda' (Baumgartner \& Jones, 2009)? In periods of stability, administrators tinker with arrangements in an effort to bring about incremental improvement without threatening the status quo (Baumgarnter, 2011). 'Pragmatic gradualism', where things move forward 'on a gradual path, testing responses, slowing down or speeding up as circumstances permit' (O'Sullivan, 2005, p. 175) suit proximate policy-makers because they can undo any harm that may arise, quickly, unobtrusively and without institutional upheaval. The absence of investment in enabling processes and essential negotiation prior to the implementation of the Reform, creates a significant impediment to realising the desired outcomes. Those most affected by the reform of initial teacher education, the HEIs, and the schools were asked to implement a reform agenda that was to be resource neutral (Sugrue \& Solbrekke, 2015, p. 2). At a period of severe austerity, between 2007 and 2015 funding to HEIs was cut by $38 \%$, while student numbers increased by $25 \%$ (Boland, 2015). Within this context, no capital was made available to invest in new supports or structures. Those at the 'chalk face', the HEI staff, and co-operating teachers or 'street level bureaucrats' who are operationalising policy change have been marginalised from the design of the new reform agenda. Although individual HEIs have introduced innovative models of working with a small selection of partner schools, there has been no formalised, systematic approach to the kind of professional development and framework for professional development such a reform process requires. Furthermore, there is perhaps a power dynamic that needs to be interrogated. Research evidence indicates that despite the high value attached to collaboration, most school-university teacher education partnerships remain HEI-led (Furlong et al., 2000; Menter et al., 2006). Schools need to be empowered to become more actively involved in leading school-university partnerships. For such partnerships to succeed, they must be meaningful and beneficial to schools. Finally, no 
review has been undertaken in relation to the initial teacher education agenda. Such a review, which is continuous, process-oriented and participatory (Brinkerhoff, 2002), is therefore long overdue.

In relation to the introduction of a revised induction/probation process, the initial consultation on the Career Entry Professional Programme (CEPP) was both extensive and thorough, despite the short eight-week period allocated for the process. While CEPP was suspended, with little revision it was recast as 'Droichead' and piloted in schools. The decision to devolve greater levels of responsibility to schools, principals and individual teachers that are at the heart of CEPP and now Droichead, was made by Minister Quinn in 2012, who in haste sought to detraditionalise the culture of teacher induction and probation. Seeking to implement a mutation of European teacher education policy in an Irish context, the state-led change was communicated to teachers, and the failure to engage realistically with them has led to an impasse. Asking teachers and principals to comply with a Council's policy, which imposes an additional burden on them in terms of out-of-school time and administration, and which breaks down the traditional collegiality of schools where teachers are expected to assess their peers, at a time, 'when teachers have become the group of Irish civil servants hardest hit by national budgetary cuts (Mulcahy and McSharry, 2012 p.98), has caused high levels of frustration among teachers. The disjuncture between the rhetoric of partnership which is so much part of the language of the Council, and the absence of a willingness by the Council to value real partnership and to support it appropriately, has drained the goodwill of teachers. The Council has failed to recognise that it has a significant role to play in the space between policy development and implementation and that it needs not just be an advocate for teaching, but for teachers. The reality of reform is challenging, and partnership cannot be mandated. Rather it demands all involved to 'come together in new, less hierarchical ways in the service of teacher learning' (Zeichner, 2010, p. 89).

\section{References}

Baumgartner, F. R. (2011). Ideas and Policy Change. A lecture delivered at Governance: Symposium on Policy Paradigms and Social Learning, Suffolk University, Boston, 11.02.2011.

Baumgartner, F. R., \& Jones, B. D. (2009). Agendas and Instability in American Politics. Chicago:

University of Chicago Press.

Boland, T. (2015). A Dialogue on the Future Funding of Higher Education in Ireland. Retrieved 16.08.2016 from http://www.hea.ie/sites/default/files/ria_tb_funding_speech_v2_oo2.pdf.

Brinkerhoff, J. M. (2002). Assessing and improving partnership relationships and outcomes: a 
proposed framework. Evaluation and Program Planning, 25(3), 215-231.

Bruton, R. (2016). Minister's response to Parliamentary Question regarding School Placement, 21.06.2016. Retrieved 05.07.2016 from https://www.kildarestreet.com/wrans/?id=2016-06-21a.409. Cochran Smith, M. (2011). Trends and Challenges in Teacher Education: National and International Perspectives. In F. Waldron et al. (Eds.), Re-imagining Initial Teacher Education: Perspective on Transformation (pp 29-53). Dublin: The Liffey Press.

Conway, P., Murphy, R., Rath, A., \& Hall, K. (2009). Learning to Teach and its Implications for the Continuum of Teacher Education: A Nine Country Cross National Study. Report to the Teaching Council. Cork: University College. Retrieved 19.11.2009 from http://www.teachingcouncil.ie/_ fileupload/Publications/LearningToTeach-ConwayMurphyRathHall-2009_10344263.pdf. Coolahan, J. (Ed.) (1994). Report on the National Education Convention. Dublin: Stationery Office. Coolahan, J. (2003). Attracting, Developing and Retaining Effective Teachers: Country Background Report for Ireland. Dublin: Department of Education and Science.

Coolahan, J. (2011). Address by Professor John Coolahan at the Launch of the Forum on Patronage and Pluralism in the Primary Sector. Retrieved 08.07.2016 from http://www.education.ie/en/PressEvents/Speeches/2011-Speeches/SP11-04-19A.html\#sthash.VjkDqJbt.dpuf.

Coolahan, J., Hussey, C., \& Kilfeather, F. (2012). The Forum on Patronage and Pluralism in the Primary Sector: Report of the Forum's Advisory Group. Dublin: Stationery Office.

Cottrell, S. (2012). IPPN CEO's Speech, delivered at the IPPN Annual Conference. Retrieved 05.07.2016 from http://www.ippn.ie/index.php?option=com_mtree\&task=att_download\&link_ $\mathrm{id}=3827 \& \mathrm{cf} \_\mathrm{id}=24$.

Cunneen, M., \& Harford, J. (2016). The Principal Route: Gender Matters. In K. Fuller, \& J. Harford (Eds.), Gender and Educational Leadership: Women Achieving Against the Odds (pp. 147-174). Oxford: Peter Lang.

Department of Education and Skills (2011). Literacy and Numeracy for Learning and for Life: The national strategy to improve literacy and numeracy among children and young people 2011-2020. Dublin: Department of Education and Skills.

Department of Education and Skills (2012). OECD Review on Evaluation and Assessment Frameworks for Improving School Outcomes: Country Background Report for Ireland. Dublin. Retrieved 10.08.2016 from http://www.oecd.org/edu/school/Country\%2oBackground\%2oReport\%20for\%2oIreland\%20 -\%2oEvaluation\%2oand\%2oAssessment\%2oFrameworks.pdf.

Department of Education and Skills (2016). Key statistics. Retrieved 10.08.2016 from http://www. education.ie/en/Publications/Statistics/Key-Statistics/Key-Statistics-2015-2016.pdf.

Devine, D. (2005). Welcome to the Celtic Tiger? Teacher Responses to immigration and increasing ethnic diversity in Irish schools'. International Studies in Sociology of Education, 15(1), 49-70.

Fuller, K., \& Harford, J. (Eds.) (2015). Gender and Educational Leadership: Women Achieving Against the Odds. Oxford: Peter Lang.

Furlong, J., Barton, L., Miles, S., Whiting, C., \& Whitty, G. (2000). Teacher Education in Transition: re-forming teaching professionalism. Buckingham: Open University Press. 
Gleeson, J. (2004). Concurrent Teacher Education (Post-primary) in the Republic of Ireland: Some Issues and Trends. In A. Burke (Ed.), Teacher Education in the Republic of Ireland: Retrospect and Prospect (pp. 43-53). Armagh: Centre for Cross-Border Studies.

Gleeson, J. (2000). Sectoral interest versus the common good? Legitimation, fragmentation and contestation in Irish post-primary curriculum policy and practice. Irish Educational Studies, 19(1), 16-34. doi: 10.1080/0332331000190105

Harford, J. (2010). Teacher education policy in Ireland and the challenges of the $21^{\text {st }}$ century.

European Journal of Teacher Education, 33(4), 349-360.

Halasz, Gabor (2016). School-university partnership for effective teacher learning. Issues Paper for the seminar co-hosted by ELTE Doctoral School of Education and Miskolc-Hejőkeresztúr KIP Regional Methodological Centre 13.05.2016.

Heinz, M (2008). The composition of applicants and entrants to teacher education programmes in Ireland: trends and patterns. Irish Educational Studies, 27(3), 223-240.

Heinz, M. (2013). Why choose teaching in the Republic of Ireland? - Student teachers' motivations and perceptions of teaching as a career and their evaluations of Irish second-level education.

European Journal of Educational Studies, 5(1), 1-17.

Hyland, A. (2012). A Review of the Structure of Initial Teacher Education Provision in Ireland:

Background Paper for the International Review Team. Dublin: Department of Education and Skills. INTO Directive on Droichead. (2016). Retrieved 29.07.2016 from http://www.into.ie/ROI/

NewsEvents/LatestNews/Title,29379,en.php.

IPPN (2012). E-scéal 298 - CEPP - Update from IPPN Meeting with Teaching Council. Retrieved 30.07.2016 from http://www.ippn.ie/index.php/146-resources/e-sceals/6572-e-sceal-298-cepp-updatefrom-ippn-meeting-with-teaching-council.

Kellaghan, T. (2002). Preparing teachers for the 21st century: Report of the working group on primary preservice teacher education. Dublin: Stationery Office.

Looney, A. (2014). Curriculum Politics and practice: from 'implementation' to 'agency. Irish Teachers' Journal, 2(1), 7-14.

Menter, I., Brisard, E., \& Smith, I. (2006). Convergence or Divergence? Initial Teacher Education in Scotland and England. Edinburgh: Dunedin.

Moran, A. (2008). Challenges surrounding widening participation and fair access to initial teacher education: can it be achieved? Journal of Education for Teaching International Research and Pedagogy, 34(1), 63-77.

Mulcahy, C., \& McSharry, M. (2012). The Changing Face of Teacher Education in Ireland: A major overhaul or a cosmetic review? Educational Research Journal, 1(2), 91-103.

Mutton, T. (2015). Partnership in Teacher Education. In The Teacher Education Group (2015) Teacher Education in Times of Change (pp. 201-216). Bristol: Policy Press.

Nicholls, K. (2015). Mediating Policy: Greece, Ireland, and Portugal before the Eurozone Crisis. London and New York: Routledge.

O’Doherty, T., \& Deegan, J. (2009). Mentors, Not Models: supporting teachers to be empowered in 
an Irish context. Research in Comparative and International Education, 4(1), 22-33.

O’ Doherty, T. (2014). Defining Moments in Policy Development, Direction, and Implementation in Irish Initial Teacher Education Policy. CEPS Journal, 4(4), 29-49.

O’Doherty, T. (2015). Teacher Education in the Republic of Ireland: A challenging and changing landscape'. In The TEG Group. Teacher Education in times of change (pp. 125-141). Bristol University: Policy Press.

O’ Doherty, T., \& Harford, J. (2016). Building Partnerships in Initial Teacher Education in Ireland. In M. Peters, B. Cowie, \& I. Menter (Eds.), A Companion to Research in Teacher Education. USA: Springer.

O’Donoghue, T., \& Harford, J. (2010). Troubling some Generalisations on Teacher Education in the English-Speaking World: The Case of the Republic of Ireland'. South Africa Journal of Education, 30(1), 91-104.

O’Donoghue, T., \& Harford, J. (2011). A Comparative History of Church-State Relations in Irish Education. Comparative Education Review, 53(3), 315-341

Ó Neill. S. (2015). Unpublished data on School Placement, submitted to the Teaching Council. O'Sullivan, D. (2005). Cultural Politics and Irish Education since the 1950s: Policy paradigms and power. Dublin: IPA.

OECD (1991). Review of National Policies for Education: Ireland. Paris: OECD.

OECD LEED (2006). Forum on Partnerships and Local Governance. Successful Partnerships: a guide.

Paris and Vienna: OECD.

OECD (2015). Schooling Redesigned: Towards innovative learning systems. OECD Publishing. Paris. Sahlberg, P., Munn, P., \& Furlong, J. (2012). Report of the International Review Panel on the structure of initial teacher education provision in Ireland: Review conducted on behalf of the Department of Education and Skills. Dublin: Department of Education and Skills.

Schleicher, A. (Ed.) (2012). Preparing Teachers and Developing School Leaders for the $21^{\text {st }}$ Century: Lessons from around the World: Paris: OECD Publishing.

Sugrue, C., \& Solbrekke, T. D. (2015). Policy rhetorics and resource neutral reforms in higher education: their impact and implications?. Studies in Higher Education. Retrieved 29.07.2016 from http://www.tandfonline.com/doi/full/10.108o/03075079.2015.1036848. doi: $10.1080 / 03075079.2015 .1036848$

Smyth, E., Darmody, M., McGinnity, F., \& Byrne, D. (2009). Adapting to Diversity: Irish Schools and Newcomer Students. Dublin: ESRI.

Smyth, E., Conway, P., Leavy, A., Darmody, M., Banks, J., \& Watson, D. (2016). Review of the Droichead Teacher Induction Pilot Programme. Dublin: The Teaching Council and ESRI.

Teaching Council (2011a). Policy on the Continuum of Teacher Education. Maynooth: Teaching Council.

Teaching Council. (2011b). Initial teacher education: Criteria and guidelines for programme providers. Maynooth: Teaching Council.

Teaching Council (2013). Guidelines on School Placement. Maynooth: Teaching Council. 
Teaching Council (2012). Annual Report 2011-2012. Maynooth: Teaching Council.

Teaching Council (2015). Droichead: A Guide for Schools. Maynooth: Teaching Council.

Walsh, J. (1999). A new partnership in Education; from consultation to legislation in the nineties.

Dublin: Institute of Public Administration.

Wanni, N., Hinz, S., \& Day, R. (2010). Good practices in educational partnerships guide: UK-Africa

Higher and Further Education Partnerships. London: The Africa Unit, UK/Africa Partnerhsips in HE/ FE.

Zeichner, K. (2008). The United States. In T. O’ Donoghue, \& C. Whitehead (Eds.), Teacher Education in the English-Speaking World: Past, Present and Future (pp. 7-22). USA: Information Age Publishing.

\section{Biographical note}

Judith Harford is Associate Professor and Director of the Professional Master of Education (PME) at the School of Education, University College Dublin. She has published internationally in the areas of history of education and teacher education policy. She is Coordinator of the Teacher Education Policy in Europe Network and a Convener of the Teacher Education Research Network of the European Educational Research Association (EERA). She is Consulting Editor to the Australian Journal of Teacher Education and series editor for Peter Lang: Oxford ('Re-Thinking Education' Series). She has served on several committees and working groups of the Irish state Department of Education and Skills and the Teaching Council of Ireland in relation to initial teacher education and teacher induction. She is a Fellow of the Royal Historical Society (London) and an International Clinical Practice Fellow of the American Association of Teacher Educators.

Teresa O'DoherTy is Dean of Education at Mary Immaculate College, Limerick. She has published internationally in the areas of history of education and teacher education policy. She is a member of a wide range of academic and professional committees on national and international levels, including being past Chair and now member of the Executive Committee of SCoTENS, invited member of the NCCA Early Childhood and Primary Committee, Teacher Education Policy in Europe Network and the Teacher Education Group (TEG). She has been appointed to State Examinations Commission, and has extensive experience as an External Examiner in universities in Scotland, Northern Ireland, and Ireland. 